\title{
INTERNATIONAL TREATIES AND LAW OF ENVIRONMENT IN INDIA: AN OVERVIEW
}

Dr. Ram Charan Meena, (Assistant Prof.)

Government Law College, Ajmer (Rajasthan)-305001

ORCID: https://orcid.org/0000-0002-2866-6942

Email: rcmeena9011@gmail.com

Electronic version

URL: http://www.researchambition.com

DOI: https://doi.org/10.53724/ambition/v6n2.05

ISSN: 2456-0146

Vol. 6, Issue-II, August 2021

Page No. 27 - 35

Publisher

Welfare Universe

Electronic reference/Article is to be Cited:

Dr. Ram Charan Meena, (2021). International Treaties And Law Of Environment In India: An Overview. Research Ambition: An International Multidisciplinary e-Journal, ISSN 2456-0146, 6(II), 27-35. https://doi.org/10.53724/ambition/v6n2.05

CResearch Ambition: An International Multidisciplinary e-Journal 2021. This Open Access article is published under a Creative Commons Attribution Non-Commercial 4.0 International License https://creativecommons.org/licenses/by-nc/4.0/, which permits non-commercial reuse, distribution, and reproduction in any medium, provided the original work is properly cited. For citation use the DOI. For commercial re-use, please contact editor email:- publish2017@gmail.com By accessing the work you hereby accept the Terms. Non-commercial uses of the work are permitted without any further permission from Research Ambition: An International Multidisciplinary eJournal provided the work is properly attributed. 


\title{
INTERNATIONAL TREATIES AND LAW OF ENVIRONMENT IN INDIA: AN OVERVIEW
}

\author{
Dr. Ram Charan Meena, (Assistant Prof.) \\ Government Law College, Ajmer (Rajasthan)-305001 \\ ORCID: https://orcid.org/0000-0002-2866-6942 \\ Email: rcmeena9011@gmail.com
}

\begin{abstract}
To address environmental issues that India and other countries face, it is essential and very important to commence action at all levels like global, regional, national, local, and community. It is not adequate to have international agreements, treaties and instruments on environmental issues and various problems but completion, implementation and enforcement of these policies and agreements to a large extent determine their impact and effectiveness. In the last few decades, there has been an increasing concern and consciousness about the need to protect the environment, nationally and internationally. Under the structure of the Indian Constitution, a number of Articles are enumerated in which environmental duties to preserve the natural resources of the country have been stated like Articles 48-A and 51-A[g]. Additionally, the Constitution also provides procedures in Articles 252 and 253 for adopting national legislations in regard to the needs of the States. The constitutional mandates and other environmental laws or regulations in India effective, successful and urgent need to streamline enforcement. The creative and innovative role of Indian Judiciary and National Green Tribunal [NGT] has been significant and laudable in this era. In this research paper, an effort has been made to momentarily outline the various Indian legislations and international treaties relating to the environment, which are mainly and more relevant to protect and improve the environment in India. The enforcement, scope and limit of these legislations has also been critically examined and evaluated in systematically manner. Protection of the environment and keeping ecological balance in Indian scenario unaffected is a task which not only the Government but also every individual, association, society, industry and corporation must undertake. It is a social compulsion and fundamental duty enshrined in Article $51-\mathrm{A}[\mathrm{g}]$ of the Indian Constitution.
\end{abstract}

Keywords: Environmental Protection, International Treaties, Air Pollution, Water Pollution, PIL, Indian Constitution and Judiciary.

\section{Introduction}

What is the object or purpose of International Environmental Law, is it an ethical statement, deterrence or a socializing instrument? If it is an ethical statement, which many of the framework or agenda conventions seem to be, is it merely inspirational? If it is anticipated as deterrence, why are there not more international forums for dispute resolution, empowered to enforce agreements? If it is intended as a 
socialization method, is it working? ${ }^{1}$ To address environmental issues that India and other countries face, it is essential and very important to commence action at all levels like global, regional, national, local, and community. It is not adequate to have international agreements and instruments on environmental issues and various problems but completion, implementation and enforcement of these policies and agreements to a large extent determine their impact and effectiveness.

In the last few decades, there has been an increasing concern and consciousness about the need to protect the environment, nationally and internationally. Under the structure of the Constitution of India, a number of Articles are enumerated in which environmental duties to preserve the natural resources of the country have been stated ${ }^{2}$ like Articles 48-A and 51-A[g]. Additionally, the Constitution also provides procedures $^{3}$ in Articles 252 and 253 for adopting national legislations in regard to the needs of the States. ${ }^{4}$ The Union or Central Government of India, in pursuance of the Stockholm Declaration of 1972 and acting under Article 253, adopted the Water [Prevention and Control of Pollution] Act, 1974 and the Water [Prevention and Control of Pollution] Cess Act, $1977 .^{5}$

In this present paper, an effort has been made to momentarily outline the various Indian legislations and international treaties relating to the environment, which are mainly and more relevant to protect and improve the environment in India. The enforcement, scope and limit of these legislations has also been critically examined and evaluated in systematically manner.

\section{Scale of Law of Environment}

The philosophy of Indian environmental law is resident in the judicial interpretation of laws and the Constitution and include several internationally recognized principles and theories, thereby providing some semblance of consistency between domestic and global environmental standards. The postindependence era saw a spate of legislation with the active involvement of the judiciary in the nineties. The $42^{\text {nd }}$ Amendment to the Indian Constitution in 1976 introduced principles of environmental protection in an unambiguous manner into the Constitution through Articles ${ }^{6} 48-\mathrm{A}$ and $51-\mathrm{A}[\mathrm{g}]$. The Stockholm conference is honored by references in the Air Act and the Environment Act, a result of effective

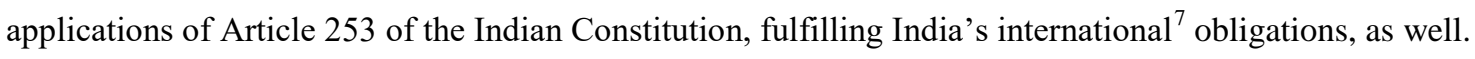
Apart from the constitutional mandate to protect and improve the environmental conditions, there are a series $^{8}$ of legislations are available on the subject but more relevant legislations for our purpose are the Forest [Conservation] Act, 1980; the Wildlife [Protection] Act, 1972; the Environment [Protection] Act, 1986; the Air [Prevention and Control of Pollution] Act, 1981; the National Environment Tribunal Act, 1995; the National Green Tribunal Act, 2010; the Biological Diversity Act, 2002 and the Hazardous Wastes [Management and Handling] Amendment Rules, 2003 and the Water [Prevention and Control of Pollution] Act, 1974 was brought about with the object to prevent, control,

1. Lavanya Rajamani [2007], Public Interest Environmental Litigation in India: Exploring Issues of Access, Participation, Equity, Effectiveness and Sustainability, Journal of Environmental Law, at pp. 293-321.

2. Nature Lovers Movement v. State of Kerala AIR 2000 Ker 131; Indian Handicrafts Emporium v. Union of India AIR 2003 SC 3240.

3. Bombay Dyeing and Mfg. Co. Ltd. v. Bombay Environmental Action Group and Ors AIR 2006 SC 1489; Narmada Bachao Andolan v. Union of India and Ors AIR 2000 SC 3751.

${ }^{4}$. State of West Bengal v. Kesoram Industries Ltd. and Ors [2004] 10 SCC 201; State of Punjab v. Devans Modern Brewaries Ltd. and Anr [2004] 11 SCC 26.

5. Madireddy Padma Rambabu v. District Forest Officer Kakinada E.G. District and Ors AIR 2002 AP 256.

6. Article 48-A: "The State shall endeavour to protect and improve the environment and to safeguard the forests and wildlife of the country."; Article 51-A[g]: "To protect and improve the natural environment including forests, lakes, rivers and wild life, and to have compassion for living creatures".

7. Intellectual Forum v. State of A.P., AIR 2006 SC 1350.

8. The Indian Forest Act, 1927; the Factories Act, 1948 and the Atomic Energy Act, 1962. 
and abate water pollution. The Indian Supreme Court has interpreted Article 32 and Article 21 to include the right to clean and healthy pollution and pollution free air and water. In Rural Litigation and Entitlement Kendra v. State of Uttar Pradesh, ${ }^{9}$ the Indian Supreme based its five comprehensive interim orders on the judicial understanding that environmental rights were to be implied into the scope of Article 21 of the Indian Constitution.

The relaxation of locus standi, in effect, fashioned a new form and figure of legal action, variously termed as Public Interest Litigation [PIL] and Social Action Litigation [SAL]. ${ }^{10}$ It is more professional and efficient in dealing with environmental matters, as these matters pertain to the rights of the community rather than the individual. The Apex Court has been taking a more holistic approach to environmental matters in recent years. It is habitually done through comprehensive orders issued from time to time, while Supreme Court appointed committees monitor the ground situation and situation. The derivation of this tendency may be seen in cases such as Ratlam case ${ }^{11}$ and Olga Tellis case. ${ }^{12}$

At the International level, international law as a rule signifies the laws of Nations that States feel themselves bound to scrutinize or monitor. In straightforward understanding, international environmental law comprises those substantive procedural and institutional rules and regulations of international law which have as their principal objective the protection and guard of the natural environment like the Precautionary and Polluter Pays theory.

The modern focus on environment is not new; the need for protection and sustainable use of natural resources of natural environment is reflected in the constitutional, legislative and policy framework as well as in the country's international commitments.. India has played a vital and important role in the international forum relating to environmental protection. It was only later than the UN Conference on the human environment at Stockholm in 1972 that a well-developed framework of environmental legislations came into continuation; that the Indian Constitution was amended ${ }^{13}$ to include the provisions relating to environmental protection. A new authority for environmental protection identified as National Council for Environmental Policy and Planning within the Department of Science and Technology was set up in 1972. This Council afterward evolved into a full-fledged Ministry of Environment and Forests [MEF] in 1998. The Indian Constitution calls upon the State to protect and improve the environment and to safeguard the forests and wildlife of the India. It also imposes a duty on every citizen of India to protect and improve the natural environment including forests, lakes, rivers and wildlife, and to have compassion for living creatures. ${ }^{14}$

Later than the Rio Conference in 1992 the Environmental Action Programme [EAP] was formulated in 1993 with the purpose of improving services and integrating environmental considerations with various development programmes in India. Agenda 21 which is an outcome of the Rio Conference was implemented in India at a much larger level. India has been very active in implementing all the objectives of Agenda 21 with the active and energetic participation of all stakeholders like the Government, international organizations, business, NGOs, and citizen groups. in view of the fact that, the Rio

\footnotetext{
9. AIR 1985 SC 652.

${ }^{10}$.Upendra Baxi [1982], Taking Suffering Seriously: Social Action Litigation and the Supreme Court, International Commission of Jurists

Review, at pp. 37-49.

11. Municipal Council, Ratlam v. Vardhichand AIR 1980 SC 1622.

12. Olga Tellis v. Bombay Municipal Corporation AIR 1986 SC 180.

13 . Vide $42^{\text {nd }}$ amendment in the Indian Constitution.

${ }^{14}$. Articles $48-\mathrm{A}$ and $51-\mathrm{A}[\mathrm{g}]$ of the Indian Constitution.
} 
Conference, extensive hard work has been made by the Indian government to integrate environmental, economic and social objectives into decision-making through new policies and strategies for sustainable development. As a nation deeply committed to enhancing the quality of life of its people and actively occupied with the international combination towards sustainable development, the Summit provided India an opportunity to re-commit ourselves to the development principles that have guided the nation for a long time. ${ }^{15}$ These principles are entrenched in the planning procedure of the country and therefore the need for a distinct national strategy for sustainable development was not felt.

India also played a vital and major role in implementing the Millennium Development Goals adopted at the WSSD in Johannesburg in 2002. Sustainability concerns have become a fundamental component of the planning procedure. The Ninth ${ }^{16}$ Five-Year Plan explicitly recognized the synergy between environment, health, growth and development. Even in the Tenth ${ }^{17}$ Five-Year Plan the reconciliation of population growth and economic growth with environmental protection is perceived as one of the major objectives.

Precautionary Theory: The precautionary theory provides the application and function of international environmental law where there is scientific ambiguity and uncertainty. The precautionary approach began to appear in international legal instruments in the mid-1980s. This theory received official recognition in Principle 15 of the Rio Declaration, which states that where there are threats of serious or irreversible damage, there is a complete scientific shortage. Beginning with Vellore Citizens Welfare Forum v. Union of India, ${ }^{18}$ the Supreme Court has unambiguously recognized the precautionary theory as a principle of Indian environmental law. More recently, in A.P. Pollution Control Board v. M.V. Nayudu, ${ }^{19}$ the Supreme Court discussed the development of the precautionary theory or principle in Indian atmosphere.

Polluter Pays Theory: The polluter pays theory is the requirement and obligation that the costs of pollution should be borne by the person who is responsible for causing pollution and its consequential expenses. The polluter pays principle in treaty law can be traced to some of the first instruments establishing minimum rules on civil legal responsibility for damages resulting from hazardous actions and activities. ${ }^{20}$ According to Principle 16 of the 1992 Rio Declaration:

"National authorities should strive to promote the internalization of environmental costs and the use of economic tools, taking into account the view that pollution is, in principle, the cost of pollution in the public interest and international trade and the environment, should be carried without deforming."

The Apex Court has come to maintain a position where it calculates environmental damages not on the basis of a claim put forward by either party, but through an examination and inspection of the situation by the Court, keeping in mind factors such as the preventive nature ${ }^{21}$ of the award.

\section{Boundaries of Law of Environment in India}

The modern corpus of environmental law in India suffers from a various disability. It is myopic in dream, sectoral in approach and a knee jerk feedback to environmental problems. The Environment [Protection] Act, 1986, for instance, designed as an overarching umbrella legislation to deal with every conceivable

15. Annual Report of the Ministry of Environment and Forests [MEF], 2002-2003

16. Annual Report of the Ministry of Environment and Forests [MEF], 1997-2002.

17. Annual Report of the Ministry of Environment and Forests [MEF], 2002-2007.

${ }_{18}^{18}$ AIR 1996 SC 2715.

19. AIR 1999 SC 812.

20. Indian Council for Enviro-Legal Action v. Union of India AIR 1996 SC 1446.

${ }^{21}$. Vellore Citizens Welfare Forum v. Union of India AIR 1996 SC 2715. 
feature of environment has by and large remained a law regulating problems and issues of pollution. Lack of vision, in foreseeing environmental problems, not evolving appropriate policies and plans besides nondynamic, reactive [rather than being, pro-active] legislative laws, in tackling the difficult and ever challenging environmental issues and problems ${ }^{22}$ appear to be at the root of the activist stance of the courts of law.

It is not that the environment has never been an issue and problem in India; it is just that the internalization of pro-environment and pro-ecological behavior is absence in the Indian environmental laws. Quite a few environmental legislations do not have the support of a policy document. The Wildlife [Protection] Act, 1972; the Forest [Conservation] Act, 1980; the Water [Prevention and Control of Pollution] Act, 1974; the Water [Prevention and Control of Pollution] Cess Act, 1977 and the Air [Prevention and Control of Pollution] Act, 1981, are only a few examples of such stand-alone documents. The approach and method adopted by the pollution control bodies may be conveniently called 'command and control', where laws exhibit a precautionary rather than a proactive role. The command being the laying down of standards and pollution limits, while the control being the power to remove water or power supply of erring units, the imposition of penalties and fines, or even imprisonment. The boundaries leading to weak fulfillment of environmental laws in India are as follows discussed:

\subsection{Frail Enforcement}

Enforcement is frail and environment management degenerates into disaster management. Consequently, the impact of non-existent or merely formal inspection on enforcement draws a very weak response from firms towards fulfillment. In the case of M.C. Mehta v. Union of India, ${ }^{23}$ a closure of all mines within a 5 k.m. radius of Badkal Lake and Surajkund [a tourist place] was ordered after a report submitted by NEERI on the pollution caused by mining. Mining activities had been going on without any consent stipulated under the Air Act. There was complete defilement of the Mines Act 1952 and the Explosives Act. The decision on a PIL filed by. Mr. M.C. Mehta alleged that the state of Haryana has failed to implement the PCB norms and policies.

\subsection{Lack of Flexibility}

The formulation of legislations or laws and standards is over-ambitious. In such a situation the levels of fulfillment would be low. Absolute or complete standards have to be adhered to. These standards are usually neither technology based nor performance based, nor are they related to the volume of pollution being generated. Thus, even with severe enforcement, the environment quality may continue to deteriorate. Over-ambitious standards discourage firms from making investments in pollution abatement technologies.

\subsection{Weak Monitoring System}

Lack of technically expert manpower leads to improper monitoring as scientific assessment of the level of pollution generated by firms becomes complicated. According to the EPA, the State PCBs are required to have a technically competent Board of Members, in the case of the Rajasthan PCB, out of 15 members, 11 were from the bureaucracy with 1 technical member. In Maharashtra, out of 13 members, 6 were from the bureaucracy with 2 technical. In contrast was the PCB of Goa that had 15 members, out of which 10 were

\footnotetext{
22. Evaluation of Environmental Laws and Proposals for Reforms: A Report, prepared by the Centre for Environmental Law Education Research and Advocacy Research Team, Mumbai, 1998.

23. AIR 1996 SC 1977.
} 
technical and 3 from the bureaucracy. In the case mentioned above it was held in the case of M.C. Mehta that keeping Delhi clean is not an easy task, but then it is not an impossible one either. What is required in initiative, selfless zeal and dedication and professional pride, elements which are sadly lacking here?

\subsection{Lack of Funds}

Another most important constraint is the lack of funds. A study found that low level of funding is one of the significant factors behind weak monitoring. Due to lack of funds, the PCBs lack adequate infrastructure facilities and services like laboratories and monitoring equipment, required for the execution of their responsibilities. Also, it was held that, the Municipal Corporation of India is wholly negligent in the discharge of their duties under law. Those authorities which are entrusted with the pollution control effort cannot be allowed to sit with folded hands for the alleged reason that they do not have any financial or other means to control pollution and protect the environment.

\subsection{Lack of Effectual Punitive Actions}

As mentioned before, there is lack of an effectual punitive and preventive mechanism in case of noncompliance. The penalties that are imposed on the firms in case of non-compliance is extremely stumpy and irrespective of the extent of fulfillment and the quantity and quality of emissions. A defaulting firm, irrespective of the extent of pollution, faces a fine of only Rs.10,000 or imprisonment up to three months, which is bailable. Also, the problem of pendency of cases in the Court room compounds the trouble. With justice delayed, justice is denied. Moreover, in the southern State of Kerala, the villagers have been fighting a legal case ${ }^{24}$ against the pollution of Chaliyar river by a rayon factory for 35 years. In Rajasthan, only two convictions have been obtained despite nearly 7,000 cases filed in the Court against air and water polluters. Scarce inspectors, corrupt officials and lenient Courts aid the procedure of noncompliance.

\section{Environment and Courts}

In the case of A.P. Pollution Control Board v. M.V. Nayudu, ${ }^{25}$ the Apex Court recognized and referred to the need for establishing Environmental Courts which would have the benefit of expert advice from environmental scientists/technically qualified persons, as part of the judicial process followed by a refined discussion of the views of jurists in different countries.

Also, in M.C. Mehta v. Union of India, ${ }^{26}$ where the Indian Supreme Court held that in as much as environment cases involve assessment of scientific data, it was desirable to set-up environment courts on a regional basis with a professional Judge and two experts, keeping in view the expertise required for such adjudication. Another judgment was Indian Council for Enviro-Legal Action v. Union of India, ${ }^{27}$ in which the Apex Court observed in well manner that Environmental Courts having civil and criminal jurisdiction must be established to deal with the environmental issues in a speedy manner.

In Kanpur Tanneries or Ganga Pollution case, ${ }^{28}$ is among the most important water pollution case in India. It discusses numerous legal provisions and legal duties of municipal bodies and pollution control boards. In this case, alarming details were about the extent of pollution in the river Ganga due to the inflow of sewage and waste matter from Kanpur, the Supreme Court came down heavily on the Municipality. It

\footnotetext{
24. The Member-Secretary, Kerala State Board for Prevention \& Control of Water Pollution, Kawadiar, Trivandrum v. The Gwalior Rayon Silk Manufacturing [Weaving] Company Ltd., Kozhikode and Ors AIR 1986 Ker 256.

25. [1999] 2 SCC 718.

${ }^{26}$. [1986] 2 SCC 176.

27.1996 (3) SCC 212.

28 . M.C. Mehta v. Union of India AIR 1988 SC 1037.
} 
emphasized that it is the Nagar Mahapalika of Kanpur that has to bear the most important accountability for the pollution of the river near Kanpur city.

In the case of Attakoya Thangal v. Union of India, ${ }^{29}$ lack of sufficient ground water resources, drinkable water and huge scale withdrawals with electric or mechanical pumps which can reduce the water sources, causing seepage or imposition of saline water from the surrounding Arabian Sea was the reason for the petitioner to approach the Supreme Court. The local administration had initiated a plan to augment water supply, by digging wells and by drawing water from those existing wells to meet increasing needs. The petitioners, sought restraint of the administration from implementing the scheme, by the issuance of suitable writs or directions. The Supreme Court held that:

"The right to life is much greater than the right to animal existence and its virtues are manifold as that of life. In these areas the priority of human needs and a new value system have been recognized. The right to fresh and clean water and the right to free and natural air are attributes of the right to life as these are the basic elements that sustain life."

A situation of total lack of interest of the government in the city of Cuttack, which led to a very serious problem of water pollution. ${ }^{30}$ The city was under the grip of a severe problem of water pollution ranging from sewage water clogging, direct inflow of sewage into the river to non-existence of a sewage treatment plants, thereby contaminating water and resulting in various types of water borne diseases. The Supreme Court held that the city of Cuttack, with its historic heritage, was in the Centre a gigantic water pollution crisis on account of the inaction of the State in setting up of a waste treatment plant causing serious health and sanitation problems. After going into the constitutional provisions and the recommendations of the State Pollution Control Board, which had openly disclosed about the drinking water and health status in the city, the Supreme Court directed the State to immediately take necessary steps to prevent and control water.

In Almitra H. Patel v. Union of India, ${ }^{31}$ the Supreme Court of India reiterated the observations made in Wadehra's case: ${ }^{32}$ Historic and famous city of Delhi, the Capital of India, is one of the most polluted cities in the world. The authorities and Government are responsible for pollution control and environment protection has not been able to provide natural clean and healthy environment to the residents of Delhi. The ambient air is so much polluted that it is difficult to breathe for a man. More and more persons are suffering from respiratory diseases and throat infections. Yamuna river, the main source of drinking water supply is the free dumping place for untreated sewerage and industrial waste matter. Apart from air and water pollution, the city is almost an open dustbin. Garbage scattered here and there is a common sight in Delhi city. The Supreme Court directed the authorities to take immediate necessary steps to control pollution and protect the environment.

'Sustainable development' means that which meets the needs of the present times without compromising on the ability or skills of future generations to meet their own needs or desires. The Apex Court in case of Vellore Citizens Welfare Forum v. Union of India, ${ }^{33}$ elaborately discussed the theory of 'sustainable development' which has been accepted as part of the law of the land in India. The precautionary principle

${ }^{29}$. [1990] 1 KLT 580.

30. M.C. Mehta v. State of Orissa AIR 1992 Ori 225.

31 . AIR 2000 SC 1256.

32. B.L Wadehra [Dr.] v. Union of India AIR 1996 SC 2969.

${ }^{33}$. AIR 1996 SC 2715. 
and the polluter pays principle are fundamental features of sustainable development. The 'precautionary principle' makes it compulsory ${ }^{34}$ for the State Government to anticipate prevent and attack the causes of environment degradation. The Supreme Court observed thus:

"There is no hesitation to believe that in order to protect the two lakes i.e., Badhkal and Surajkund from environmental degradation, it is necessary to stop the construction activity in the vicinity of the lakes."

According to the 'polluter pays principle', the financial cost of preventing or treating pollution damages should be at the expense of those undertakings that cause pollution. The polluter pays principle has been held to be a sound principle and as interpreted ${ }^{35}$ by the Supreme Court, it means that the absolute liability for damage to the extension of the environment is not only to compensate the victims of pollution, but also the cost of restoring the deprivation of the environment. Remedy of the damaged environment is only part of the process of 'sustainable development' which thus polluters are liable to pay the cost to the individual victims as well as to pay the cost of reversing the degraded ecosystem.

The above study clearly shows that the Apex Court has played a very important role for the protection and improvement of the environmental situation in India. The jurisdiction of the Court has been expanded and prolonged by way of PIL. The creative and inventive role of judiciary has been significant and deserving of praise.

\section{Conclusion}

The main challenge for India in implementing the international commitments is to struggle poverty and also development on sustainable basis. In June 1972, Mrs. Indira Gandhi, the then Prime Minister of India, emphasized at the first UN-sponsored Conference on environment that poverty is the most horrible form of pollution and the most urgent issue facing the international community. Since then, India has been reminding the industrialized world that so long as poverty remains the main stumbling block in its road to development, its hard work to defend the environment and protect resources would not bear the essential fruits. For India it is true that, as well as for other nations of the South, removal of poverty and environmental protection are two sides of the same coin. Throughout the past decade, India has ratified many of the international conventions and treaties related to environment protection and have taken a number of initiatives to execute them at the domestic level. Even though India has been very energetic in all the international forums relating to environmental protection and has signed almost all the multilateral agreements relating to the environment accept very little, still much needs to be done at the domestic level for their implementation. The actual challenge before India is how to conserve its environment, meet the basic needs of its growing population on an overburdened land, accomplish the necessary energy necessities of the people and yet leave a heritage for future generations so that they may also enjoy the gift of nature which the present generation is uncontrollably exploiting. Further, as directed by the Supreme Court, environment studies shall be made a compulsory subject at school and college levels in graded system so that there should be general growth of awareness. Finally, protection of the environment and keeping ecological balance unaffected is a task which not only the government but also every individual, association and corporation must undertake. It is a social obligation and fundamental duty enshrined in Article 51-A[g] of the Indian Constitution.

$* * * * * * * * * * * * * * * * * * * * * * * * * * * * * * * *$

${ }^{34}$. M.C. Mehta v. Union of India [1997] 1 Camp L.J. 199 [SC].

35. Indian Council for Enviro-Legal Action v. Union of India AIR 1996 SC 1446. 